\title{
FUNCTIONAL CAPACITY AND ITS ASSOCIATED FACTORS IN THE ELDERLY WITH LOW BACK PAIN
}

\author{
Roger Palma ${ }^{1}$, Marta Helena Souza de Conti ${ }^{2}$, Natasha Mendonça Quintino ${ }^{1}$, Marcia Aparecida Nuevo Gattil ${ }^{2}$, \\ Sandra Fiorelli almeida Penteado Simeão², alberto de Vitta ${ }^{2}$
}

\begin{abstract}
Objective: To assess the level of functional capacity in subjects aged 60 years and older, who have lower back pain, and its association with demographic, socioeconomic, work-related, lifestyle-related and disease mentioned variables. Methods: A cross-sectional study was conducted with 246 elderly registered at the Family Health Strategy of Vila São Paulo, Bauru,SP, Brazil, who reported lower back pain and were sampled by a two-stage cluster technique. The subjects were interviewed at home by using a multidimensional instrument (demographic; socioeconomic aspects; life style; work characterization; disease mentioned), and also the IPAQ, the Nordic and the Roland Morris questionnaires. A bivariate and multivariate des-
\end{abstract}

criptive logistic regression analysis was carried out. Results: The prevalence of lower back pain in men was of $25.1 \%$ and in women it was of $35.1 \%$. The mean score in the functional capacity assessment was $10.46 \pm 5.62$. A fraction of $67.5 \%$ of the elderly demonstrated an inappropriate functional capacity. The age group from 70 to 80 years old, the subjects reporting three or more diseases and the sedentary group presented an independent association with inappropriate functional capacity. Conclusion: The older, sedentary subjects and who reported more than three diseases presented low functional capacity.

\section{Level of Evidence III, Cross Sectioning.}

Keywords: Low back pain. Family Health. Activities of daily living. Personal autonomy. Aged. Risk factors.

Citation: Palma R, Conti MHS, Quintino NM, Gatti MAN, Simeão SFAP, Vitta A. Functional capacity and its associated factors in the elderly with low back pain. Acta Ortop Bras. [online]. 2014;22(6):295-9. Available from URL: http://www.scielo.br/aob.

\section{INTRODUCTION}

Low back pain is one of the most common musculoskeletal disorders in the world, affecting approximately $70 \%$ to $85 \%$ of the population at some time in life, ${ }^{1}$ and can cause large decrease of the construct "functional capacity" that indicates the maximum possible functionality that a person can achieve in a given time, i.e., it interferes with the autonomy and quality of life. Thus, the functional capacity emerges as an ideal value for the elderly in order to live independently and autonomously, being able to perform physical and mental activities necessary for maintaining his basic activities such as value: bathing, dressing, performing personal hygiene, transfer and move himself, getting up, eating, keeping continence, preparing meals, having financial control, etc. ${ }^{2}$

For the assessment of functional capacity of individuals with low back pain, various instruments are proposed in literature, such as the questionnaires "Roland Morris", "Oswestry Low Back Pain", "Disability Questionnaire", "Waddell Disability Index" and "Sickness Impact Profile". Among these, the Roland Morris questionnaire has been widely used in research and clinical practice since it has been translated, adapted and validated for the Brazilian population. ${ }^{3}$

The Family Health Strategy (FHS), implemented in Brazil in 1994, aims at the reorganization of primary care in the country, according to the precepts of the Unified Health System (SUS). The professionals involved in primary care should consider the National Policy and the Elderly Statute, which ensures healthy aging, through actions such as population surveys and intervention programs recommended by the Ministry of Health. ${ }^{4}$ Assessments such as functional capacity enable to provide information on the profile of the elderly constituting simple and useful tools in identifying the limitations and loss of autonomy of individuals. Through the functional capacity evaluation strategies to promote health of the elderly aiming at delaying or preventing disabilities can be defined.

Considering the theoretical framework, this study aimed to verify the level of functional ability in individuals aged 60 years and older with low back pain and its association with sociodemographic variables, work-related, lifestyle and referred diseases.

All the authors declare that there is no potential conflict of interest referring to this article.

\footnotetext{
1. Universidade Paulista (UNIP), Bauru, SP, Brazil.

2. Universidade do Sagrado Coração (USC), Bauru, SP, Brazil.

Work developed at Programa Estratégia Saúde da Família da Vila São Paulo, Bauru, SP, Brazil and Universidade do Sagrado Coração de Bauru, SP, Brazil. Correspondence: Alberto De Vitta, Rua Ir. Arminda, 10-50, Jd Brasil, 17011-160, Bauru, SP, Brazil. albvitta@yahoo.com.br
} 


\section{MATERIALS AND METHODS}

This is a cross-sectional study of a population of individuals aged 60 years and older of the areas covered by the FHS Vila São Paulo, in the city of Bauru, SP, Brazil.

The target population was limited to elderly above 60 years old living in areas circumscribed to the Family Health Strategy in the Vila São Paulo region, Northern region of Bauru, which has two FHS teams with eight community workers. This region consists of four districts: Vila São Paulo, Jardim Ivone, and Pousada da Esperança I and II, with an estimated population of 12,600 inhabitants.

The number of seniors enrolled in the FHS program was of 643 subjects. One sample per cluster was used in two-stages, the first stage comprised the two family health units distributed in Vila Sao Paulo - basic selection units - where the stratified sampling proportional to the amount of elderly enrolled for coverage area of each community worker was performed. In the second stage, the elderly, considered the sample unit, were chosen randomly from the register of families seen by the health agent. Thus, the sample size was calculated considering the elderly population (643 individuals), the prevalence of $24 \%, 5,6$ a sampling error of $3 \%$ and a confidence level of $95 \%$, estimating a total of 360 seniors in the FHS of the referred region, including 160 individuals from area 401 (neighborhoods Pousada da Esperança I and II) and 200 individuals from the area 701 (Vila São Paulo and Jardim Ivone). Among the 360 elderly, 246 reported low back pain, constituting, then, the subject of the present study.

The subjects were informed of all stages of the study, the voluntary nature of participation, the possibility to leave the survey at any time and the right to confidentiality of individual data. Those who agreed to participate in the research signed a Free and Informed Consent.

Data collection was carried out between December 2011 and March 2012. The research was approved by the Research Ethics Committee of Universidade do Sagrado Coração Proc. $n^{\circ} 201 / 11$.

The researchers visited the households covered by the FHS accompanied by the community workers of each sector. Interviews with randomly selected subjects were performed and were excluded elderly unable to answer the questionnaires, such as mentally disabled and individuals who had suffered a stroke and presented cognitive impairment due to other neurological diseases. In the case of closed homes, after three attempts, another subject was drafted from the list.

The first questionnaire answered was about demographic characteristics (gender, age, marital status and skin color), socioeconomic factors (education and income), labor (sitting work, or standing, crouching, lying, kneeling, vibration and/or trepidation, lifting weight, repetitive motion), lifestyle (physical activity, smoking, hours on TV, frequency on TV, hours at the computer, frequency on the computer) and type of diseases. The position at work and type of movements (sitting, standing, crouching, lying, kneeling, vibration and/or trepidation, loading weight, repetitive movements) were characterized by the perception of the respondent identifying four options (never, rarely, usually, always), which best characterized the frequency of exposure. The level of physical activity of the elderly was assessed using the International Physical Activity Questionnaire (IPAQ), short version, proposed by the World Health Organization (WHO) and Centers for Disease Control and Prevention (CDC). This instrument evaluates physical activities in leisure time, as moving from one place to another, household services and occupational activities. ${ }^{7}$

Pain in the lumbar spine was observed through the Nordic questionnaire, adapted to the Brazilian culture. ${ }^{8}$ Low back pain was defined as pain or discomfort in the last twelve months, not related to trauma or other problem. At the time of the interview the following question was asked to the elderly: "Have you had pain in the lumbar spine (lower back) in the last year?". For more specificity about the location of pain in addition to verbal questioning, an image of the regions of the vertebral column in different colors was presented, to identify the lumbar region. This type of tool is valid and reliable for measuring pain in the population, as it makes the individual very specific on locating the pain. ${ }^{8}$

The dependent variable was the functional capacity compromised due to musculoskeletal pain, measured by the Brazilian version of the Rolland-Morris questionnaire(Brazil) validated by Nusbaum. ${ }^{9}$ This instrument was translated into Portuguese language and adapted to Brazilian culture, presenting a high test-retest reliability (ICC 0.94) and inter-rater (ICC 0.95). ${ }^{9}$

Rolland-Morris contains a list of 24 phrases that the respondent indicates if the question describes his status on the day of application. The list, according to the author, has some phrases that people use to describe the pains they feel in the back. For each marked sentence one point is counted, so the total score ranges from zero to 24 points. The higher the total score, the greater the functional impairment of the individual. The minimum score is zero and represents no impact of pain on the person. There were defined as having low functional capacity individuals with scores greater than or equal to 14 in the Rolland-Morris questionnaire (cutoff that characterizes the presence of significant disability due to low back pain). ${ }^{9}$

\section{Data Analysis}

The data were entered into a database and analyzes were stratified by gender using the statistical program SPSS, version 10.0 (SPSS, Chicago, USA). The analysis was performed using a descriptive and an analytical approach. In the descriptive approach distributions of absolute and relative frequencies for categorical variables were made and the analytical bivariate analysis was performed using the chi-square, and then, multivariate binary logistic regression, following the hierarchical model. The adopted method for the introduction of the variables in the models was the "backward stepwise". A significance level of $5 \%$ and a confidence interval (Cl) of $95 \%$ were considered, with adjusted calculation of "odds ratios". ${ }^{10}$

\section{RESULTS}

In Table 1, we observed that there was a higher frequency of elderly, of both genders, aged between 60 and 69 years (56.2\% for men and $53.8 \%$ for women); $55.6 \%$ of men and $46.2 \%$ of women had $0-4$ years of schooling; $50.3 \%$ of men and $76.3 \%$ of women were married; $66.6 \%$ of men and $77.4 \%$ of women had an income of 2-5 minimum wages; $51.6 \%$ of men and $50.5 \%$ of women reported having three or more diseases and $86.9 \%$ 
of men and $64.5 \%$ of women were sedentary. Of the elderly respondents, $70.9 \%$ were retired, and of these, $14.1 \%$ were still working by performing the same activities.

Regarding the variables related to work (Table 2) there have been higher percentages in work activities that individuals performed in the standing position $(95.4 \%$ for men and $92.5 \%$ for women), standing leaning forward $(93.5 \%$ for men and $89.2 \%$ for women), repetitive movements $(77.1 \%$ for men and $98.2 \%$ for women) and lifted and carried weight $(62.1 \%$ men and $81.7 \%$ women).

The mean score on the assessment of functional capacity, obtained in the Roland-Morris disability questionnaire was 10.46 \pm 5.62 . A fraction of $67.5 \%$ of the elderly had no adequate functional capacity while $32.5 \%$ had. On the responses to the Roland-Morris, the most frequently mentioned items were: "I change my position" with 98 annotations for men and 57 for women; "I walk slower" with 110 and 62 annotations, respectively; "I use handrails to climb stairs" with 97 and 60 annotations; "I need support to rise from a chair" with 83 and 46; "I dress up more slowly" with 101 and 67; "I stand for short periods" with 107 and 41; "I try not to bend or crouch" with 99 and 68; "I feel pain most of the time" 90 and 53; "I face problems to put on socks" with 84 and 49; "I avoid heavy work at home" with 125 and 76, and "I climb stairs more slowly" with 100 and 70 annotations, respectively.

Table 3 shows significant associations between inadequate functional capacity and age, household income, reported

Table 1. Absolute and relative frequency of the sociodemographic variables, related diseases and level of physical activity of the elderly (Bauru, SP, 2011).

\begin{tabular}{c|c|c}
\hline \multirow{2}{*}{ Factors } & \multicolumn{2}{|c}{ Gender } \\
\cline { 2 - 3 } Age group & Masculine & Feminine \\
\hline 60 - 69 years old & $86(56.2 \%)$ & $50(53.8 \%)$ \\
\hline 70 - 80 years old & $67(43.8 \%)$ & $43(46.2 \%)$ \\
\hline Years of schooling & & \\
\hline 0 - 4 years & $85(55.6 \%)$ & $43(46.2 \%)$ \\
\hline 5 - 8 years & $68(44.4 \%)$ & $50(53.8 \%)$ \\
\hline Ethnic group & & \\
\hline White & $77(50.3 \%)$ & $38(40.9 \%)$ \\
\hline Black & $22(14.4 \%)$ & $12(12.9 \%)$ \\
\hline mulatto & $54(35.3 \%)$ & $43(46.2 \%)$ \\
\hline Marital status & & \\
\hline Married & $77(50.3 \%)$ & $71(76.3 \%)$ \\
\hline Widow, single, divorced & $76(49.7 \%)$ & $22(23.7 \%)$ \\
\hline Income & & \\
\hline Up to 1 minimum wage & $52(34.0 \%)$ & $21(22.6 \%)$ \\
\hline Two to five minimum wages & $101(66.6 \%)$ & $72(77.4 \%)$ \\
\hline Related diseases & & \\
\hline Up to two & $74(48.4 \%)$ & $46(49.5 \%)$ \\
\hline Three or more & $79(51.6 \%)$ & $47(50.5 \%)$ \\
\hline Level of physical activity & & \\
\hline Sedentary & $133(86.9 \%)$ & \\
\hline Active & $20(13.1 \%)$ & \\
\hline
\end{tabular}

Acta Ortop Bras. 2014;22(6):295-9
Tabela 2. Absolute and relative frequency according to variables related to work of the elderly (Bauru, SP, 2011)

\begin{tabular}{|c|c|c|}
\hline \multirow{2}{*}{ Factors } & \multicolumn{2}{|c|}{ Gender } \\
\hline & Masculine & Feminine \\
\hline \multicolumn{3}{|c|}{ Repetitive movements } \\
\hline Always/usually & $118(77.1 \%)$ & $83(98.2 \%)$ \\
\hline Never/rarely & 35 (22.9\%) & $10(10.8 \%)$ \\
\hline \multicolumn{3}{|c|}{ Vibration/trepidation } \\
\hline Always/usually & $44(28.8 \%)$ & $55(59.1 \%)$ \\
\hline Never/rarely & $109(71.2 \%)$ & $38(40.9 \%)$ \\
\hline \multicolumn{3}{|c|}{ Lifting and caring weight } \\
\hline Always/usually & $95(62.1 \%)$ & $76(81.7 \%)$ \\
\hline Never/rarely & $58(37.9 \%)$ & $17(18.3 \%)$ \\
\hline \multicolumn{3}{|l|}{ Kneeling position } \\
\hline Always/usually & 87 (56.9\%) & $47(50.5 \%)$ \\
\hline Never/rarely & $66(43.1 \%)$ & $46(49.5 \%)$ \\
\hline \multicolumn{3}{|l|}{ Siting position } \\
\hline Always/usually & $41(26.8 \%)$ & $28(30.1 \%)$ \\
\hline Never/rarely & $112(73.2 \%)$ & $65(69.9 \%)$ \\
\hline \multicolumn{3}{|c|}{ Siting lifting weight } \\
\hline Always/usually & $19(12.4 \%)$ & $17(18.3 \%)$ \\
\hline Never/rarely & $134(87.6 \%)$ & $76(81.7 \%)$ \\
\hline \multicolumn{3}{|c|}{ Siting and leaning body } \\
\hline Always/usually & $50(32.7 \%)$ & $29(31.2 \%)$ \\
\hline Never/rarely & $103(67.3 \%)$ & $64(68.8 \%)$ \\
\hline \multicolumn{3}{|l|}{ Standing position } \\
\hline Always/usually & $146(95.4 \%)$ & $86(92.5 \%)$ \\
\hline Never/rarely & $7(4.6 \%)$ & $7(7.5 \%)$ \\
\hline \multicolumn{3}{|c|}{ Standing position leaning forward } \\
\hline Always/usually & $143(93.5 \%)$ & $83(89.2 \%)$ \\
\hline Never/rarely & $10(6.5 \%)$ & $10(10.8 \%)$ \\
\hline
\end{tabular}

illnesses and physical activity level, indicated by the $x^{2}$ test. Also using the $x^{2}$ test, it was possible to identify, in Table 4 , significant associations between inadequate functional capacity and repeated movements and the sitting position.

The results of logistic regression analysis (Table 5) showed that age $(p=0.001)$, the amount of reported diseases ( $p$ $=0.02)$ and the level of physical activity $(p=0.04)$ showed independent association with inadequate functional capacity.

\section{DISCUSSION}

It has been observed in this study a higher frequency of elderly aged between 60 and 69 years old, married, with low education and income of two to five minimum wages, which concurs with other research conducted with the elderly. ${ }^{11,12}$

Regarding work, it was noticed that the elderly, in their occupational activities, performed "always/usually" repetitive movements, lifting and carrying weight and worked in a standing position and standing leaning forward. In Pelotas it was observed that most of the population of this age group worked in a sitting position, with repetitive movements, vibration and/ or trepidation and carrying weight. ${ }^{13}$

In the present study, $67.5 \%$ of the elderly had no adequate 
Table 3. Bivariate analysis of the functional capacity in relation to sociodemographic variables, diseases and level of physical activities of the elderly (Bauru, SP, 2011).

\begin{tabular}{|c|c|c|c|}
\hline \multirow{2}{*}{ Factors } & \multicolumn{2}{|c|}{ Functional capacity } & \multirow{2}{*}{$\mathrm{x}^{2}$ test } \\
\hline & Inadequate & Adequate & \\
\hline \multicolumn{4}{|l|}{ Gender } \\
\hline Masculine & $100(60.2 \%)$ & $53(66.2 \%)$ & \multirow{2}{*}{$p>0.05$} \\
\hline Feminine & $66(39.8 \%)$ & $27(33.8 \%)$ & \\
\hline \multicolumn{4}{|l|}{ Age group } \\
\hline $60-69$ years old & $81(48.8 \%)$ & $51(63.8 \%)$ & \multirow{2}{*}{$p<0.05$} \\
\hline $70-80$ years old & $85(51.2 \%)$ & $29(36.2 \%)$ & \\
\hline \multicolumn{4}{|l|}{ Years of schooling } \\
\hline 0.4 years & $45(56.2 \%)$ & $83(50.0 \%)$ & \multirow{2}{*}{$p>0.05$} \\
\hline $5-8$ years & $35(43.8 \%)$ & $83(50.0 \%)$ & \\
\hline \multicolumn{4}{|l|}{ Ethnic group } \\
\hline White & $36(45.0 \%)$ & $79(47.6 \%)$ & \multirow{3}{*}{$p>0.05$} \\
\hline Black & $11(13.8 \%)$ & $23(13.9 \%)$ & \\
\hline mulatto & $33(41.3 \%)$ & $58(38.5 \%)$ & \\
\hline \multicolumn{4}{|l|}{ Marital status } \\
\hline Married & $46(57.5 \%)$ & $101(60.8 \%)$ & \multirow{2}{*}{$p>0.05$} \\
\hline Widow, single, divorced & $34(42.5 \%)$ & $65(39.2 \%)$ & \\
\hline \multicolumn{4}{|l|}{ Income } \\
\hline Up to 1 minimum wage & $30(37.5 \%)$ & $43(25.9 \%)$ & \multirow{2}{*}{$p<0.05$} \\
\hline Two to five minimum wages & $50(62.5 \%)$ & $123(74.1 \%)$ & \\
\hline \multicolumn{4}{|l|}{$\begin{array}{l}\text { Related diseases } \\
\end{array}$} \\
\hline Up to two & $93(56.0 \%)$ & $27(33.8 \%)$ & \multirow{2}{*}{$p<0.05$} \\
\hline Three or more & $73(44.0 \%)$ & $53(66.2 \%)$ & \\
\hline \multicolumn{4}{|l|}{ Level of physical activity } \\
\hline Sedentary & $70(87.5 \%)$ & $138(83.1 \%)$ & \multirow{2}{*}{$p<0.05$} \\
\hline Active & $10(12.5 \%)$ & $28(16.9 \%)$ & \\
\hline Active & & & \\
\hline
\end{tabular}

Table 4. Bivariate analysis of the functional capacity in relation to work characteristics (Bauru, SP, 2011)

\begin{tabular}{|c|c|c|c|}
\hline \multirow{2}{*}{ Factors } & \multicolumn{2}{|c|}{ Functional capacity } & \multirow{2}{*}{$\mathrm{x}^{2}$ test } \\
\hline & Inadequate & Adequate & \\
\hline \multicolumn{4}{|c|}{ Repetitive movements } \\
\hline Always/usually & $131(78.9 \%)$ & $70(87.5 \%)$ & \multirow{2}{*}{$p<0.05$} \\
\hline Never/rarely & $35(21.1 \%)$ & $10(12.5 \%)$ & \\
\hline \multicolumn{4}{|c|}{ Vibration/trepidation } \\
\hline Always/usually & $94(56.6 \%)$ & $53(66.2 \%)$ & \multirow{2}{*}{$p>0.05$} \\
\hline Never/rarely & $72(43.4 \%)$ & $27(33.8 \%)$ & \\
\hline \multicolumn{4}{|c|}{ Lifting and caring weight } \\
\hline Always/usually & $47(28.3 \%)$ & $28(35.0 \%)$ & \multirow{2}{*}{$p>0.05$} \\
\hline Never/rarely & $119(71.7 \%)$ & $52(65.0 \%)$ & \\
\hline \multicolumn{4}{|l|}{ Kneeling position } \\
\hline Always/usually & $79(47.6 \%)$ & $33(41.2 \%)$ & \multirow{2}{*}{$p>0.05$} \\
\hline Never/rarely & $87(52.4 \%)$ & $47(58.8 \%)$ & \\
\hline \multicolumn{4}{|l|}{ Siting position } \\
\hline Always/usually & $125(75.3 \%)$ & $52(65.0 \%)$ & \multirow{2}{*}{$p<0.05$} \\
\hline Never/rarely & $41(24.7 \%)$ & $28(35.0 \%)$ & \\
\hline \multicolumn{4}{|c|}{ Siting lifting weight } \\
\hline Always/usually & $142(85.5 \%)$ & $68(85.0 \%)$ & \multirow{2}{*}{$p>0.05$} \\
\hline Never/rarely & $24(14.5 \%)$ & $12(15.0 \%)$ & \\
\hline \multicolumn{4}{|c|}{ Siting and leaning body } \\
\hline Always/usually & $117(70.5 \%)$ & $50(62.5 \%)$ & \multirow{2}{*}{$p>0.05$} \\
\hline Never/rarely & $49(29.5 \%)$ & $30(37.5 \%)$ & \\
\hline \multicolumn{4}{|l|}{ Standing position } \\
\hline Always/usually & $10(06.0 \%)$ & $4(05.0 \%)$ & \multirow{2}{*}{$p>0.05$} \\
\hline Never/rarely & $156(94.0 \%)$ & $76(95.0 \%)$ & \\
\hline \multicolumn{4}{|c|}{$\begin{array}{l}\text { Standing position leaning } \\
\text { forward }\end{array}$} \\
\hline Always/usually & $14(08.4 \%)$ & $6(07.5 \%)$ & \multirow{2}{*}{$p>0.05$} \\
\hline Never/rarely & $152(91.6 \%)$ & $74(92.5 \%)$ & \\
\hline
\end{tabular}

Table 5. Multivariate analysis of logistic regression. Final model for independent associations with inadequate functional capacity (Bauru, SP, 2011)

\begin{tabular}{|c|c|c|}
\hline Factors & $p$ value & Adjusted $\mathrm{OR}^{\star} / \mathrm{Cl} 95 \%$ \\
\hline \multicolumn{3}{|l|}{ Age group } \\
\hline 60 - 69 years old & \multirow{2}{*}{0.001} & 1.00 \\
\hline 70 - 80 years old & & $2.25(1.19-4.21)$ \\
\hline \multicolumn{3}{|l|}{ Related diseases } \\
\hline Up to two & \multirow{2}{*}{0.02} & 1.00 \\
\hline Three or more & & $1.39(1.22-1.72)$ \\
\hline \multicolumn{3}{|c|}{ Level of physical activity } \\
\hline Sedentary & \multirow{2}{*}{0.04} & 1.00 \\
\hline Active & & $2.71(1.34-5.47)$ \\
\hline
\end{tabular}

functional capacity averaging $10.46 \pm 5.62$ points on the Roland-Morris disability questionnaire, like other research on the same topic. ${ }^{14-16}$

Also in this study it was found that the elderly aged 70 or older were 2.25 times more likely to have not adequate functional capacity. Other authors have noticed increased disability in older ages. ${ }^{17,18}$ With advancing age the human body begins a slow degenerative process, resulting in the gradual decrease in functional capacity that may lead the elderly to disability, with loss of cognitive domain and physical dysfunction which contribute to the reduction of his autonomy. ${ }^{19}$

Regarding the level of physical activity, sedentary elderly had 2.21 times the odds of not having adequate functional capacity. In Canada it was noticed that sedentary subjects had $33 \%$ higher odds of functional disability than active ones, ${ }^{20}$ and in the United States association was found between low functional capacity and low level of physical ability among participants of a survey with individuals suffering from low back pain. ${ }^{21}$ Physical activity is an important predictor of functional capacity in patients with low back pain. The more active elderly lives better, because physical activities allow the preservation and minimization of debilitating bodily pains and organic changes. It is important to consider that, although the physical performance is modified over the years, with proper and regular practice of physical activity, respecting the biological individuality, these modifications will be restricted, favoring the extension of life, enriching the quality of life, contributing to rehabilitation of interdependent physiological functions. ${ }^{22}$ Seniors with three or more diseases showed 39\% more chances of inadequate functional capacity. These data were confirmed in the city of Guatambu, SC, Brazil, where the elderly who were affected by five or more comorbidities had a prevalence of 2.84 times less likely to have an adequate functional capacity. ${ }^{23} \mathrm{~A}$ population-based study in São Paulo, Brazil, ${ }^{24}$ showed that chronic diseases have a strong influence on the functional capacity of the elderly. The presence of hypertension increases by $39 \%$ the chance of the elderly being dependent in instrumental activities of daily living (IADL), heart disease increases by $82 \%$, arthropathy in $59 \%$ and pulmonary disease in $50 \%$. For the IADL dependency and activities of daily living (ADL), the odds more than doubled for the presence of each of these chronic diseases. Chronic non-communicable 
diseases are more common among the elderly, and are the most disabling. Successful aging becomes the result of the interaction of multi-dimensional factors, which include items related to physical health, mental issues, independence in daily life, economic and psychosocial factors. ${ }^{21}$

One limitation of this study refers to the cross-sectional design that did not allow establishing a temporal relationship of cause and effect between variables. Another point is the sample design that investigated the prevalence of inadequate functional capacity in only one region of low social class, where there are high rates of individuals with low educational level, hindering a more heterogeneous sample, ideal for this type of analysis.

\section{CONCLUSION}

In the population investigated in this study, we observed a significant association between inadequate functional capacity in the elderly over 70 years old, with reports of three or more diseases and sedentary. These data may be useful as preventive strategies in health units and encourage changes in routine care to the elderly health, investing in preventive actions.

\section{ACKNOWLEDGEMENTS}

A special acknowledgement is made to the elderly and the Family Health Program of Vila São Paulo and to FAPESP (São Paulo State Research Foundation) for funding the project.

\section{REFERENCES}

1. Bento AAC, Paiva ACS, Siqueira FB. Correlação entre incapacidade, dor Roland Morris, e capacidade funcional - SF-36 em indivíduos com dor lombar crônica não específica. E-scientia. 2009;2(1):1-18.

2. [OMS] Organização Mundoal da Saúde, CIF: Classificação Internacional de Funcionalidade, Incapacidade e Saúde [Centro Colaborador da Organização Mundial da Saúde para a Família de Classificações Internacionais, org.; coordenação da tradução Cassia Maria Buchalla]. São Paulo: Editora da Universidade de São Paulo - EDUSP; 2003.

3. Ocarino JM, Gonçalves GGP, Vaz DV, Cabral AAV, Porto JV, Silva MT. Correlação entre um questionário de desempenho funcional e testes de capacidade física em pacientes com lombalgia. Rev Bras Fisioter. 2009;13(4):343-9.

4. Brasil. Ministério da Saúde. Departamento de Atenção Básica. Política nacional de atenção básica. Brasília: Ministério da Saúde; 2006.

5. Ramos LR, Rosa TEC, Oliveira ZM, Medina MCG, Santos FRG. Perfil do idoso em área metropolitana na região sudeste do Brasil: resultados de inquérito domiciliar. Rev Saúde Pública. 1993;27(2):87-94.

6. Trelha CS, Nakaoski T, Franco SS, Dellaroza MSG, Yamada KN, Cabrera M, et al. Capacidade funcional de idosos restritos ao domicílio, do conjunto Ruy Virmond Carnascialli, Londrina/PR. Semina: Ciências Biológicas e da Saúde. 2005;26(1):37-46.

7. Craig CL, Marshall AL, Sjöström M, Bauman AE, Booth ML, Ainsworth BE, et al International physical activity questionnaire: 12-country reliability and validity. Med Sci Sports Exerc. 2003;35(8):1381-95

8. Pinheiro FA, Tróccoli BT, Carvalho CV. Questionário Nórdico de Sintomas Osteomusculares: validade do instrumento como medida de morbidade. Rev Saúde Pública. 2002;36:307-12.

9. Nusbaum L, Natour J, Ferraz MB, Goldenberg J. Translation, adaptation and validation of the Roland-Morris questionnaire--Brazil Roland-Morris. Braz J Med Biol Res. 2001; 34(2):203-10.

10. Zar JH. Biostatistical analysis. 5th ed. New Jersey: Prentice-Hall; 2010.

11. Alves LC, Leite IC, Machado CJ. Fatores associados à incapacidade funcional dos idosos no Brasil: análise multinível. Rev Saúde Pública. 2010;44(3):468-78.

12. Gonçalves SX, Brito GEG, Carvalho EAO, Carvalho DB, Rolim IB, Lucena

Acta Ortop Bras. 2014;22(6):295-9
EMF. Capacidade funcional de idosos adscritos à estratégia saúde da família no município de João Pessoa - PB. Rev Bras Ci Saúde. 2011;15(3):287-94.

13. Silva MC, Fassa AG, Valle NCJ. Dor lombar crônica em uma população adulta do Sul do Brasil: prevalência e fatores associados. Cad Saúde Pública 2004;20(2):377-85.

14. Resnik L, Dobrykowski E. Outcomes measurement for patients with low back pain. Orthop Nurs. 2005;24(1):14-24.

15. Falcão FCOS. Qualidade de vida e capacidade funcional em idosos com dor lombar crônica [dissertação]. Campinas: Universidade Estadual de Campinas, Faculdade de Educação; 2006.

16. Jordan K, Dunn KM, Lewis M, Croft P. A minimal clinically important difference was derived for the Roland-Morris Disability Questionnaire for low back pain J Clin Epidemiol. 2006;59(1):45-52.

17. Foss MHD, Martins MRI, Ikehara E, Rampazo F, Tinti G, Detoni M, et al. Qualidade de vida de funcionários com dor lombar. Rev Dor. 2009;10(2):106-12.

18. Sousa C, Mesquita C, Sousa A. Dor Lombar na Escola Superior de Tecnologia da Saúde do Porto. Um estudo de prevalência. Ifisionline. 2010;2(2):16-24.

19. Maciel ACC, Guerra RO. Influência dos fatores biopsicossociais sobre a capacidade funcional de idosos. Rev Bras Epidemiol. 2007;10(2):178-89.

20. Ledoux E, Dubois JD, Descarreaux M. Physical and psychosocial predictors of functional trunk capacity in older adults with and without low back pain. $J$ Manipulative Physiol Ther. 2012;35(5):338-45.

21. Filho IT, Simmonds MJ, Protas EJ, Jones S. Back pain, physical function, and estimates of aerobic capacity: what are the relationships among methods and measures? Am J Phys Med Rehabil. 2002;81(12):913-20.

22. Farias RG, Santos SMA. Influência dos determinantes do envelhecimento ativo entre idosos mais idosos. Texto Contexto Enferm. 2012;21(1):167-76.

23. Santos KA, Koszuoki R, Dias-da-Costa JS, Pattussi MP. Fatores associados com a incapacidade funcional em idosos do Município de Guatambu, Santa Catarina, Brasil. Cad Saúde Pública. 2007;23(11):2781-8.

24. Alves LC, Leimann BC, Vasconcelos ME, Carvalho MS, Vasconcelos AG, Fonseca TC, et al. A influência das doenças crônicas na capacidade funcional dos idosos do Município de São Paulo, Brasil. Cad Saúde Pública. 2007;23(8):1924-30. 